\title{
Asymmetric Federalism \\ and the Political Economy of Decentralization
}

\author{
Roger D. Congleton, \\ George Mason University \\ George Mason University \\ January 5, 2006
}

\section{Introduction}

A broad range of theoretical and empirical work on federalism is based on the implicit assumption that subnational governments within federal systems are more or less equally sized and equally influential. This idea seems to be based on the intuition that the production and distribution of public services by local governments have properties similar to those of competitive firms. At a competitive Tiebout equilibrium, each government at a given level of governance in a federal system tends to be that which provides services to its residents at least cost. Consequently, all jurisdictions that produce the same mix of government services are approximately the same efficient size, and a federal system will be composed of more or less homogeneous local governments. Only efficiently-sized communities survive in a fiscally competitive environment, because least-cost producers of government services always attract residents and tax base away from less optimally sized jurisdictions.

The Tiebout model is a useful characterization of many locational decisions in which production economies and competition may be presumed to play a significant part in the decisions reached. However, the assumption of uniform jurisdictional size and power is a less useful foundation for county, city, and state levels of analysis. Here we observe significant differences in physical size, population, income, and political representation for state and local governments. In the United States, California is physically the third largest state with $11 \%$ of the citizens, whereas Wyoming, the sixth largest state includes less than $1 \%$ of the U. S. population. Requejo (1996) notes that New South Wales includes $35 \%$ of the population of Australia, whereas Tasmania includes less than 3\%. North Rhine Westfalia includes some 21\% of the population of Germany, 
whereas Bremen includes less than 1\% of the population. Uttar Pradesh includes $16 \%$ of the population of India, whereas Sikkim includes less than a twentieth of one percent. That population and population densities vary so widely implies that demands for local services also tend to vary widely among these regional governments and, moreover, implies that political power within their respective democratic central governments is also likely to vary widely by state, lander, and province.

That regional interests and bargaining power vary is important for fiscal federalism, because national constitutions do not fully specify the degree of decentralization within a nation at any single point in time or through time. Rather, the degree of decentralization is determined by a series of political bargains within and between national and regional legislatures in which both the details of policy and the powers to make policies are negotiated and renegotiated through time. Consequently, any differences in the bargaining power and interests among participating governments is likely to affect the distribution of fiscal and regulatory authority adopted. ${ }^{1}$

Of course, it is possible that unequal populations and resources have no effect on the political bargains that determine decentralization. Each state, province, autonomous region, lander, and city might have essentially identical regulatory, tax, and expenditure authority. The distribution of political power within a federal system could be bound by a political generality rule, as implicitly assumed in most analyses of fiscal federalism.

However, in practice unequal bargaining power has often lead to agreements that generate different degrees of authority to different state and local governments.

For example, in Spain, Navarra and the Basque communities have formal tax and expenditure powers beyond those of the other "autonomous communities." Galicia and Catalonia have special authority over education, language, and culture. In Canada, Quebec

$1 \quad$ Yet, surprisingly very little work has been done asymmetric federalism. Tiebout, 1956, and Oates, 1972, pioneered the economic analysis of fiscal federalism and intergovernmental relationships. Inman and Rubinfeld (1997) provide a nice survey of issues in subsequent literature. Molander (2004) provide a more international review of fiscal federalism in unitary states. Qian and Weingast (1997) elaborate the role that federalism can play in solving various commitment and information problems.

None of these papers or books includes any reference or comments on asymmetric forms of federalism. Requejo (1996) analyses some general features of existing asymmetries within modern states. Congleton, Bacarria, and Kyriacou (2003) analyze the political foundations of asymmetric distribution of authority within nation states and international organizations. 
has special powers to encourage the use of the French language and protect the French-Canadian culture. In the United Kingdom, the Scottish Parliament has significantly more policy-making authority than the Welsh Parliament. In the United States, Indian reservations have their own specific taxing and regulatory authority that differ from those of ordinary state governments. California, the most populous state, has unique powers of environmental regulation. ${ }^{2}$ In China, Hong Kong has been granted unique legal and political institutions: "one country, two systems." Large cities in many countries often have powers of taxation and regulation that smaller cities lack or rarely use. New York City and Washington D. C. have their own income and sales taxes.

Asymmetries are also common among the members of large international organizations. In the European Union, some members retain more autonomy than others inasmuch as they have opted out of or delayed membership in the menu of treaties that define the responsibilities of affiliated countries. The responsibilities of members of the United Nations with respect to military armaments, human rights, and environmental regulations are similarly defined through a series of treaties with quite different signatories. Different nations formally retain different degrees of autonomy both within and without these very decentralized confederations.

Overall, the more carefully one examines the distribution of fiscal and regulatory authority within nation states and international organizations, the more asymmetries one finds. Congleton, Bacarria, and Kyriacou (2003) refers to such voluntary systems of centralization and decentralization as "menu federalism."

Although constitutional documents often formally specify federal structures of governance that constrain the permissible range of political bargains that may be reached

\footnotetext{
2 Service differences across communities may also emerge in a completely unified state where policy-making authority is completely centralized, insofar as communities may have unequal influence over the decisions of the central government because of differences in population, political heterogeneity, history, or size. For example, equal representation by population often implies unequal representation by regions or economic interests, and vice versa. Unequal influence within the central government implies that central government policies will often favor some regions or communities over others.

Analysis of variation voting power has a long and distinguished history in the public choice literature. (See for example: Mueller, 1989.) However, this form of asymmetry is not the same as that analyzed here in which regional governments acquire different degrees of local policy-making
} authority. 
regarding decentralization, it is ordinary legislation that ulitmately determines which levels of government conteol which policies taxes, and legislation, at least at the margin. This also tends to be true within unitary governments that lack some of the formal institutional features of a federal government (a provincial or regional council, or senate). In either case, fiscal responsibilities are normally distributed among many layers of more or less independent governments in a manner determined by ongoing negotiations and ordinary legislation. As a consequence, some federal and unitary states have highly decentralized fiscal and regulatory systems, while others are highly centralized. The German Länder have little power of taxation, while the substantial income tax of Sweden is a local matter, rather than a national one.

This chapter attempts to explain in economic and political terms the emergence of decentralized governance in general, and of asymmetric federalism in particular, and their implications for government finance, service levels, and intergovernmental competition.

Section II provides an illustrating example of the consequences of unequal policy-making authority at one level of governance. In general, communities with greater authority to make their own policies have a competitive advantage over their fellow communities that lack such powers. Sections III and IV analyze why communities, nonetheless, often have somewhat unequal authority to make public policies. The analysis shows that the federal structures are a natural consequence of fiscal bargaining, and that asymmetries emerge, because of differences in the perceived political risk and economic advantages associated with delegating policy-making authority to central governments. Section $\mathrm{V}$ explores other political implications of asymmetric fiscal federalism. For example, the average degree of asymmetry that emerges in under- and over-centralized states tends to differ, because different marginal states control the degree of centralization that is adopted. The asymmetries that emerge are also affected by the institutional setting in which negotiations take place. Asymmetries tend to be smaller in democracies with a very mobile population than in authoritarian regimes with a relatively less mobile population. Section VI summarizes the results and suggests further extensions.

The approach is contractarian in spirit in that decentralization is analyzed as a consequence of voluntary agreements between communities and central governments. 
This is not to deny that methods other than negotiation have generated multilevel governance, but for the most part asymmetric decentralization within modern states reflects agreements rather than wars of conquest or threats of secession. Regardless of the origins of decentralization, the existence of mutual gains provides a survivorship rationale for the continuation and success of more or less decentralized states once established. The standard tools of public choice, public finance and constitutional political economy are used to analyze the agreements that might be reached between central and provincial governments. Historical examples are used to illustrate the relevance of the analysis.

\section{Mobility and the Long Run Economic Consequences of Asymmetric Fiscal Federalism}

Asymmetric federalism exists whenever governments at the same level of geographic responsibility—-towns, counties, cities, or states—have different regulatory and fiscal powers. Such differences in policy authority create a "supply-side" source of variation in government services, regulations, and taxes in addition to the standard demand-side variation in local demand stressed in models of local fiscal competition, as developed elsewhere in this volume. Asymmetries in the supply side of the fiscal contest can have substantial effects on the distribution of services, persons, and income within a nation state or international community.

For example, consider the case in which only a single city is granted authority to use eminent domain to produce "right of ways" for light rail transport services. Suppose that the favored city sells or rents the right of ways to private railroad companies. This provides the city with a unique source of revenue and also a unique economic advantage. Both effects allow the more autonomous government to provide a more attractive fiscal and economic environment for its residents than possible for otherwise similar governments.

Light rail has the effect of reducing transport costs to city apartments, shops, and factories that operate in an otherwise competitive market. Individuals prefer to work for firms that are close to the rail lines, and consumers prefer to live and shop at stores near the rail lines_-other things being equal—because the net of transport real wages are higher and net of transport prices are lower along the rail lines. This increases net benefits 
and profits for consumers and firms located near the rail lines. Moreover, rental revenue from the right of ways allows the favored city to reduce other tax rates within the city.

Given these economic advantages, persons and firms from within the favored city and throughout the country of interest will attempt to relocate near to the rail lines of the favored city. In principle, the favored city continues expanding its rail network and attracting tax base up to the point where the marginal increase in revenue and tax base generated by an extra kilometer of new right of way equals the marginal cost of the right of way less any loss in tax base generated by investor fears concerning the use of eminent domain-or until no private firm is willing to expand its rail network because traffic densities are too low to recover its costs. The latter, of course, expands outward from the city center as immigration of capital and labor occurs.

Although there is a limit to the urban growth encouraged by this city's unique power of eminent domain, the favored city becomes an important commercial and cultural center well before this limit is reached. Its internal market and population expands; specialization increases; and wages and profits increase as productivity rise. Other cities that have to rely entirely upon private provision of rail services falter, because holdout problems make assembling long right of ways very difficult—indeed intractable-for private firms acting alone. The more autonomous city grows and prospers-while other similar cities that would have copied the strategy of the favored city are legally unable to do so.

Other local fiscal and regulatory "privileges" can have similar effects, insofar as the additional authority allows favored governments to provide a more attractive fiscal package than legally possible for other similar governments.

If favored governments take advantage of their additional authority, residents and tax base will be attracted to their communities, and those communities will prosper relative to others. In this manner, asymmetric distributions of fiscal and regulatory power may amplify preexisting asymmetries in population, wealth, and political power. The expectation of these greater regional inequalities, in turn, tend to produce additional political demands for provincial, urban, and local autonomy - but also creates demands that such asymmetries be limited. 
The next two sections analyze political gains to trade associated with reallocating fiscal and regulatory authority within under- and over-centralized states. These political gains to trade imply that asymmetries in the legally permitted scope of local policy formation will be commonplace. Section IV discusses some political and economic limits to the process of reallocating political authority among levels of government.

\section{Emergence of Asymmetric Federalism within an "Under Centralized" State}

Historically, most national governments emerged by assembling and merging local and provincial governments. In some cases, the amalgamation of regional governments was the result of military force, as might be said of modern states of Great Britain, Japan, Italy, and Germany. In others, national governments have been formed by a series of treaties among regional governments, many of which were catalyzed by military threats, as might be said of the Netherlands, the United States, and Switzerland. In either case, the resulting nation states tend to be composed of many levels of governance, and gains to political exchange between local, state, and national governments often exist. Such gains to trade tend to exist both at the time the nation state is assembled and through time as political circumstances change.

Many of these intranational political gains from trade affect the extent of decentralization - the extent to which state, county, and local governments have independent policy-making authority on particular fiscal policies and regulations. This section of the chapter analyzes the advantages of transfering authority from local to central authorities in an initially under-centralized state.

Mutual advantages from further coordination of policies at a particular level of government may arise for a variety of economic reasons, as noted in the other chapters: sharing the fixed costs of new or expanded public services, increased opportunities for social risk pooling, the internalization of regional and international externalities, advantages associated with expanded markets, and, in some cases, reduced tax competition among regional governments.

The advantage of centralizing policy-making authority, however, is largely reduced decision costs, rather than the economic advantages associated with greater coordination, because 
centralization is not the only method of solving coordination problems or of realizing economies of scale. Multilateral agreements among governments, however, are often difficult to negotiate, because they require unanimous agreement among the contracting parties. In agreeing to centralize some policy decisions, member governments (states) normally sacrifice complete political control (veto) for partial control. That is to say, centralization of policy-making authority often replaces unanimity with a somewhat less inclusive decision rule. As a consequence, the costs of coordinating policy choices fall, but a new risk is created. The service levels and cost allocations of the central authority may make one or all participants worse off_-even if constrained to policy areas in which mutual advantages from centralizing policy-making authority exist (Buchanan and Tullock, 1962).

Thus, both the advantages and the disadvantages of centralization, per se, are largely political in nature, although the benefits from increased policy coordination and from the realization of economies of scale are largely economic — as noted by several of the other chapters in this volume.

\section{A. To Centralize or Not? Political and Economic Considerations}

Consider the case in which local governments may individually choose wheher participate or not in a new centralized program that will henceforth determine a particular public policy for all member states using some form of majority rule. ${ }^{3}$

The net benefit of joining a centralized authority is partly determined by anticipated cost savings from the greater scale or scope of production as well as reduced

There are several reasons for focusing on "confederal" decisions. First, an exercise in creating a new central authority more naturally focuses attention on centralized decision making procedures and constraints. The emergence of new governmental policy-making bodies is a fairly common outcome of negotiations between a central government and local jurisdictions. Even very narrow agreements to centralize policy-making authority within a particular area often devote considerable resources to institutional design. For example, international environmental treaties generally devote more text to specifying institutional arrangements for collective decision making than to specifying environmental problems and remedies (Congleton, 1995). Second, the analysis of voluntary transfers of authority to the central government focuses attention on the decisions of potential confederal partners or service subscribers. The process of intergovernmental bargaining is too easily neglected if one focuses exclusively on the central government's interests, in which case all fiscal structures might be assumed to reflect the interests of the national government alone. 
negotiation costs and also by expectations about the manner in which potential savings are to be distributed among member states. Local governments agree to the centralized control of a service if their governments expect to realize net advantages from that control. For the purposes of this chapter, it is assumed that local political incentives are correlated with local net benefits, as tends to be the case in competitive democratic governments.

Let $\mathrm{P}_{\mathrm{ji}}$ be the probability that local government $j$ is a member of the decisive coalition on issue $i$, and let $1-\mathrm{P}_{\mathrm{ji}}$ be the probability that it is in the minority coalition. The anticipated benefit if government $j$ is a member of the majority (on service $i$ ) is $B^{M} \ddot{j}$, which rationality implies is cannot be smaller than that associated with minority status, $B^{N} j i$. Member states in the majority coalition bear cost $C^{M}{ }_{j 1}$ for public service $i$ which cannot be larger than $j$ would have paid as a member of the minority coalition, $C^{N} j$. If state $j$ does not join the confederation, or if the confederation chooses not to provide service $i$ centrally, state $j$ produces government service $i$ independently and realizes a net benefit of $N_{j i}$ from its own independent production. ${ }^{4}$

State $j$ favors service $i$ being provided by the central government iff:

$$
P_{j i}\left(B^{M}{ }_{j i}-C^{M}\right)+\left(1-P_{j i}\right)\left(B_{j i}^{N}-C^{N}{ }_{j i}\right)>N_{j i}
$$

and $N_{j i} \geq 0$.

Equation 1 makes it clear that both economic and political factors enter into decisions to provide services centrally. If both $B_{j i}^{M}-C_{j i}^{M}$ and $B_{j i}^{N_{j i}}-C_{j i}^{N}$ exceed $N_{j i}$, economic considerations are sufficient to justify centralize provision of service $i$ - given the existing political and technological constraints. In cases in which the net advantage for

\footnotetext{
$4 \quad$ It is assumed that the favored group consists of members of the ruling majority coalition. However, in some cases, minority protections may assure small states relatively preferential treatment, as for example when a minority is given effective veto power over policy. In such cases, the political risk is simply that the majority will evade the constitutional constraints. Olson and Zeckhauser (1966) note that cost sharing in NATO favored smaller nations who were able to free ride to some extent on the contributions of the United States. Vaubel (1994) argues that because unanimity grants member states equal power and thereby an equal claim on the gains from cooperation. In this manner, Vaubel argues that unanimity rules favor the smaller states of the European Union.
} 
the advantaged (majority) groups exceeds that of independent production, $B_{j i}^{M}-C_{j i}^{M}>$ $\mathrm{N}_{\mathrm{ji}}$, but those associated with the disadvantaged (minority) group are below those of independent production, $B_{j i}^{N}-C_{j i}^{N}<\mathrm{N}_{j i}$, it is clear that political considerations largely determine whether state $j$ favors centralized or independent provision of service $i$. In this latter case, both the size of the fiscal differential across majority and minority groups and the probability of being in the minority (nondecisive) coalition influence the demand for centralized services.

Once the range of services to be centrally provided is determined, the expected net benefit of participation can be computed by adding up the expected net benefits across all services. Within service areas bound by a generality rule, membership is essentially an all-or-nothing choice and all members will receive more or less the same array of services. State $j$ transfers policy-making authority in these areas to the central government if:

$$
\Sigma_{\mathrm{i}}\left\{P_{j i}\left(B^{M}{ }_{j i}-C^{M}{ }_{j i}\right)+\left(1-P_{j i}\right)\left(B^{N}{ }_{j i}-C^{N}{ }_{j i}\right)\right\}>\Sigma_{\mathrm{i}} N_{j i}
$$

The last member to join the centralized authority, the marginal member, is essentially indifferent between confederal and independent production.

Nonmembers believe that the net advantage of the entire political and economic package is less than zero. Their net benefits from additional coordination and economies of scale are too small to offset the political risks of centralization.

\section{B. The Importance of Political Institutions for Voluntary Centralization}

If confederal members are attempting to realize economies of scale in the production of government services or internalize regulatory externalities, it is clear that the number of participants matters. The more members, the greater are the economies of scale and the more fully are regulatory externalities taken into account. Consequently, both members and nonmembers have an interest in adopting institutions that reduce the perceived political risk of centralization, at least at the margin. Reduced risks induce more governments to participate and increase the economic advantages of membership.

Equations 1 and 2 imply that two general categories of institutions can reduce the downside risk of minority status: (1) adopting voting rules with a more demanding 
qualified majority and (2) reducing the central confederal government's ability to discriminate among potential members. Such institutions increase the range of services that member states can agree to provide jointly, because they increase the expected net benefits of nonmember states.

It bears noting that favorable collective choice rules can allow essentially all the potential gains from centralization to be realized. For example, a collective choice method that gives every member state the same probability of being in the majority as in the minority, as with a lottery or explicit rotation in government, generates a unanimous agreement to allow confederal production of all services in which the average net benefits of centralized joint production, adjusted for risk, are greater than those of decentralized production. Political risks are not eliminated by such institutions, but are substantially reduced for marginal members of the confederation. ${ }^{5}$ (There always remains the possibility, neglected in the present analysis, that the "natural" majority will evade the constitutional constraints.)

The risk associated with being outside the decisive coalition can also be reduced by adopting constitutional or procedural rules that limit the extent to which the central authority can discriminate among member states. For example, a policy constraint may be adopted that requires uniform treatment of all member states, as with the generality rule examined by Buchanan and Congleton (1998). A generality rule limits prospects for targeting the benefits and costs of centrally provided services, because it requires equal treatment of all members. In the limit, a generality rule makes service levels and costs identical among regions (or persons). If the disadvantage of minority status disappears, equation 1 implies that all services for which centralization yields positive net benefits will be centralized. ${ }^{6}$

Weak forms of confederation often specify unanimous agreement for the highest levels of policies. For example, under a standard international treaty, a joint political body is often created which specifies that the decision rule post signing remains some form of unanimous agreement. Within a "stronger" form of federal or confederal system the central government will use a less inhibiting form of political decision making such as majority rule. In the limit, a unanimity rule can increase the probability of being in the decisive coalition to unity, but as noted by Buchanan and Tullock, 1965, collective decision making costs may be rather large, which is noted above is a reason for replacing multilateral agreements with a standing central authority.

6 Buchanan and Congleton (1998) note that a generality restriction both increases majoritarian stability and reduce the burden of individual cycles. Dead weight cost increases with 


\section{Menu Federalism: an Alternative Political Risk-Reducing Institution}

Another institutional method of reducing political risk and expanding service membership and service areas is menu federalism. Under menu federalism, member states choose which services they will have produced centrally in much the same way that consumers select services from large firms in the marketplace. The voluntary nature of each "subscription" allows non-uniform service levels to be provided while reducing the political risk associated with discriminatory central governments, and also allows central authorities to be constrained to provide uniform services in order to avoid such discrimination.

The range of services provided members remains limited to those accepted by all member states under both symmetric and asymmetric forms of federalism. However, the "all or nothing" choice of symmetric federalism is replaced by a series of "marginal" choices by member states. The least advantaged member of a symmetric system accepts more centralized services than really desired, while the most advantaged member states accept less centralization than ideal for them. The menu approach allows each government to choose which services to centralize. This reduces membership costs for marginal and near marginal members of the confederation, while providing opportunities for additional centralization for members otherwise constrained by the concerns of marginal members.

Ignoring nonpartitionable global public goods, which make up a very small portion of government services, asymmetric federalism allows both membership and the range of centralized services to expand relative to that of uniform centralization in much the same way that ordinary consumers benefit from scale economies and coordination by purchasing goods from large firms and joining private clubs. Local government "purchase" centrally produced services whenever the cost is lower or the quality of service better than possible under independent production. $^{7}$

the square of the marginal tax rate (Browning, 1987), consequently, the dead weight burden of concentrating the tax burden on the minority is greater than it would have been under more uniform methods of taxation. That is to say, the average cost of programs increases under discriminatory majority rule with an "evenly rotating majority" relative to that under a generality rule.

Here, it bears noting that most of the services that are produced by governments are not 
In cases in which a menu like approach to centralization cannot be used on a day-to-day basis because of transactions costs, or hold out problems, opportunities to create new asymmetric federal or confederal arrangements are limited to "constitutional moments." Such moments often arise when the terms of membership are varied or new service areas are to be centralized.

In either case, both formal and informal asymmetries are likely to emerge under menu federalism as the confederal charter evolves in a piecemeal fashion to address the concerns of current and potential members, as has been the case for the European Union and United Nations.

\section{The Unequal Economic Consequences of Centralization}

In all of these cases, as noted in section II, the economic consequences of unequal policy-making authority tends to be unequal, because some states benefit more than others from centralization and others choose not to participate some of the agreements to centralize policy-making authority. nonmembers retain more policy autonomy than member-states, although at the cost of reduced scale, coordination and network economies.

If the centralized policy-making authority is well designed so that all of its policies make all member communities better off_-some members are still likely to do better than others under centralization. The communities that benefit most from increased scale and coordination are the smallest members, other things being equal. The smallest members will, thus, tend to prosper as their net of tax service and regulatory pattern improves relative to the status quo and to other members whose net gains are more modest. Communities that do not participate in the centralization are somewhat worse off, because they face stiffer competition for residents and capital.

pure public goods available globally, as is often assumed in public finance models, but rather services for which laws rather than factories are the principal method of production. Laws, taxes, and most government services are inherently excludable because law enforcement and other services are provided by individual governments.

Of course, as in the "right of way" illustration, many of these services will attract emigrants from other communities. But, of course, whether new immigrants are entitled to the same services as current residents is, itself, a matter of law. 
On the other hand, if the centralized policy-making organization is not well designed, some members will find themselves worse off than they would have been under decentralization. Nonmembers in this case may find that their circumstances improve relative to members, as residents and capital flow from losing member states to winning member states and to nonmember states.

\section{Emergence of Asymmetric Fiscal Federalism from an Overly Centralized State}

Now consider the opposite case, in which control of some government services is initially over centralized rather than under centralized. A common situation both historically and in modern times is that in which local and state governments petitions their central government for specific local privileges or new authority in a policy area of mutual interest. For example, local authorities may seek special authority to regulate, produce, tax, or distribute services that are currently exclusively within the jurisdiction of the central government. When the central government expects to profit from allowing such local authority, it will draft a charter or promulgate a law that delegates new policy-making authority to the community seeking it. When some, but not all, regions or communities secure additional policy-making authority, the result is asymmetric federalism.

\section{A. Mutual Gains from Decentralization: the Underprovision of Public Services by Leviathan}

Brennan and Buchanan $(1977,1980)$ demonstrate that a revenue maximizing central government tends to overtax its subjects and discuss several institutional methods for curtailing leviathan's power to tax. The complementary analysis of government expenditures suggests that a net revenue-maximizing state tends to under provide government services. For example, Olson (1993, 2000) and Olson and McGuire (1996) note that a net revenue-maximizing government produces services only to the extent that the expected net tax revenue is increased by providing those services. All provinces may receive local services from the central government, but central government services are likely to be provided at levels that differ from the local ideal. 
This point can be easily demonstrated by considering the underlying mathematics of the tax and public service provision by a net revenue-maximizing central government. The tax revenue of such a government may be characterized as the sum of the revenues from each of its territories:

$$
T=\sum_{j} t_{j} N_{j} Y_{j}\left(t_{j}, G_{i}\right)
$$

The taxable income of each territory is its population, $\mathrm{N} j$, times its average income, $\mathrm{Yj}$, which increases with government service level, $G i$, and falls with the national tax rate, $t j$. $G i$ is assumed for purposes of illustration to be a national public good such as transport infrastructure, law and order, environmental quality, or national defense. The cost of providing public service $i$ is

$$
C=c\left(G_{i}\right) \text {. }
$$

The public service output and tax rates that maximize net tax receipts can be characterized by differentiating the difference between equation 1 and 2 with respect to $t_{j}$ and $G_{i}$.

$$
\begin{aligned}
& \sum t j N j Y j_{t i}+N j Y j(t j, G i)=0 \\
& \text { and } \sum_{t j} N j Y j G i-C_{G i}=0 .
\end{aligned}
$$

Note that the government service is underprovided for the nation as a whole as long as $t j<1$ and $C_{G i}>0$, since maximizing national income requires $\Sigma N j Y j G i-C_{G i}=0$.

A net revenue-maximizing government underprovides both national and local public goods, because local services are provided only to the point at which the marginal increase in tax revenue equals the marginal cost of public services. Public services that increase taxable income are provided by the central government, but are underprovided, because the central government receives only part of the increase in taxable base generated by the public service. (Marginal and average tax rates are necessarily less than $100 \%$ in order to provide a return for the private initiative that actually generates the taxable base.) Public services that are valued by local residents but do not increase taxable income are not provided at all! 


\section{B. The Political Market for Local Autonomy}

The underprovision of governmental services noted by Olson implies the existence of unrealized gains to trade between a net revenue-maximizing central government and local communities. That is to say, at least some local communities will have an interest in negotiating with the central administration for the right to provide extra services. ${ }^{8}$

Each community's interest in greater autonomy varies with the endowments (wealth) of its citizenry and with the intensity of their desire for the underprovided services. Each community's ability to pay for local autonomy, whether in dollars or political favors, varies with its ability to organize negotiations with the sovereign and locally finance payments to the central authority and additional production. Together these imply that there is a maximum sacrifice that each community is willing to make to obtain local authority in every policy area. That is to say, each community has a reservation price for obtaining the power to provide (and fund) its ideal service level, and these reservation prices vary among communities. The effective demand for decentralization can be characterized by ordering community reservation prices for service autonomy from high to low. Figure 1 depicts such a demand schedule for local autonomy.

As the monopoly provider of autonomy in the service areas of interest, the central government can manipulate the political and economic "price" of autonomy to maximize the net advantage realized by the "crown." Grants of autonomy are, after all, simply another source of revenue and/or other valued services for leviathan. The central government's marginal cost for allowing local autonomy consists largely of increased administrative and security costs associated with ruling more autonomous and therefore more independent regions. Except in cases with unusual security or administrative costs, the cost of granting additional local autonomy appears to be more or less the same across communities. $^{9}$

\footnotetext{
$8 \quad$ Opportunities for mutually advantageous tax reductions may also exist if the community has a comparative advantage at providing services for leviathan.

$9 \quad$ In addition to adopting Mancur Olson's (1993) model of the provision of public services within an autocracy (under a stationary bandit), this section also adopts Olson's benign neglect of security issues.

Security issues are neglected as a method of simplifying the prose and reducing modeling
} 
For purposes of illustration, figure 1 assumes that the central government does not engage in price discrimination among communities or across service areas and that those seeking autonomy use the same methods of settlement with the sovereign. ${ }^{10}$ These assumptions allow the marginal cost curve faced by those seeking limited local autonomy to be characterized as a horizontal line. The marginal cost confronting regional, urban, and local governments is assumed to be the monopoly price of autonomy, although the specific price, however, is not of special interest for the present analysis. The focus of the present analysis is the degree to which autonomy is "purchased" by localities at a positive price. The more fiscal and regulatory areas in which local authority is obtained, the greater is the average degree of fiscal and regulatory decentralization.

Figure 1

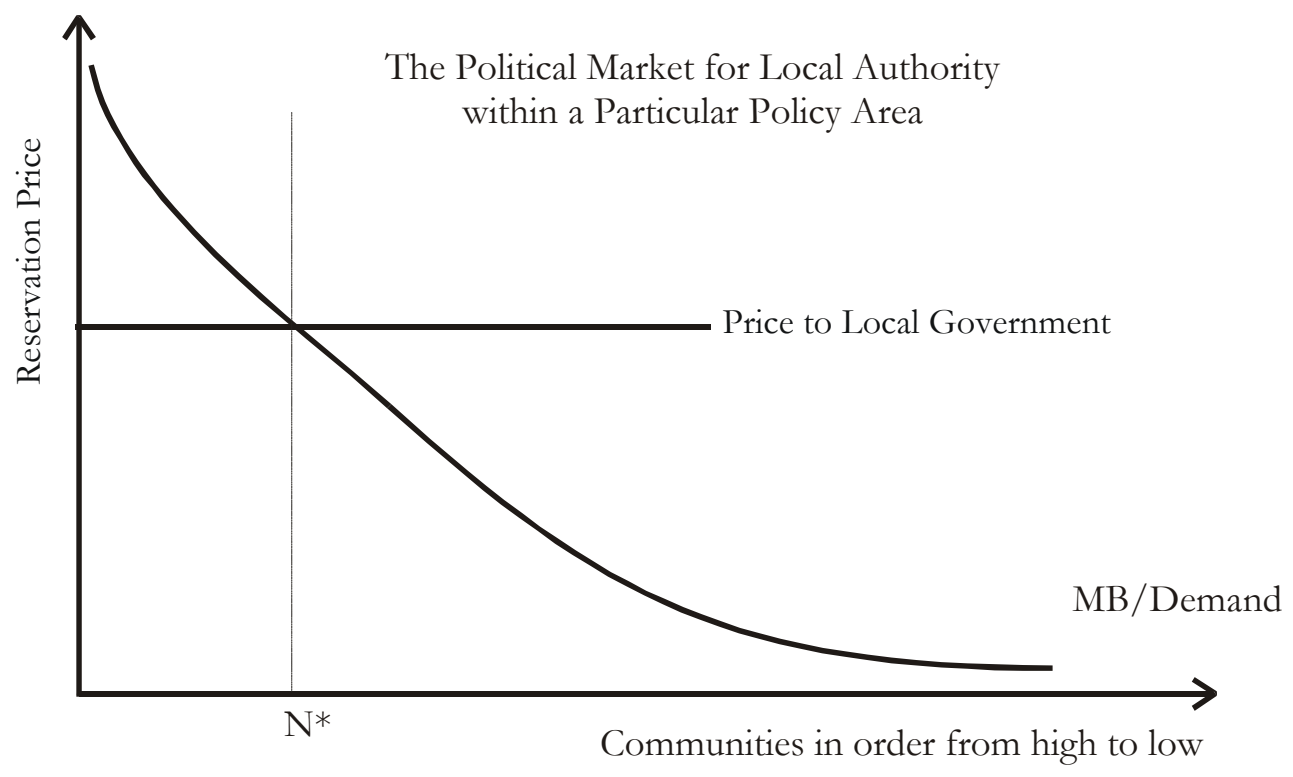

Note that asymmetric federalism is the normal result of a political market for local autonomy. Only communities to the left of the intersection of the autonomy demand and marginal

complexity. In the context of the present analysis, security concerns are interpreted as additional costs or benefits associated with decentralization. Grants of regional autonomy may increase or reduce security costs according to the particular circumstances. Autonomy makes it easier for opponents to organize and resist control by the central government; on the other hand it also reduces incentives to do so.

10 Differences in local organizational costs have historically played a role in securing local autonomy as well. For example, the existence of political, regional, or ethnic organizations clearly reduces the difficulty of organizing to "demand" local autonomy from a central government. A common language, religion, or ethnicity reduces organization costs, as does the existence of standing organizations such as churches, guilds, or local governments. Differences in organizational costs will, naturally, affect a group's reservation price for autonomy. 
cost curve obtain local autonomy in the policy area(s) of interest. Communities to the right of $\mathrm{N}^{*}$ accept the centrally provided fiscal package. As in ordinary markets, only communities willing to pay the price receive the product sold.

The comparative statics of the demand for local autonomy under leviathan are similar to those of ordinary monopoly markets. As the willingness to pay for autonomy increases and as the "price" faced by autonomy-seeking communities decline, the extent of autonomy "purchased" from the central government tends to increase. Conversely, autonomy may be relinquished by towns whose benefits from autonomy decline or costs increase as noted in the previous section.

\section{Decentralization within Overly Centralized Democracies}

Incentives within overly centralized democracies ruled by stable majority coalitions are in many ways similar to the autocratic case. A stable majority is interested in providing services and transfers to its membership. Insofar as local service levels and transfers are set to advance majority interests, tax rates tend to gravitate toward levels that maximize revenues, although elected governments normally advance broader interests than an autocrat does and normally confront binding constitutional constraints. This provides the majority with an encompassing interest in income-generating public services, but not necessarily for other public services favored by the minority. The latter implies that gains to trade between minority communities and the central government tend to exist.

The greater openness of democratic communities, however, implies that the underlying cost and risk of engaging in political activity to secure local authority tends to be smaller within democracies than within dictatorships. Political movements favoring greater independence from central authorities may, therefore, organize with less fear of repressive consequences. This implies that effective demand will be larger, other things being equal, and that there will be more local autonomy within a democracy ruled by a stable majority coalition than within an otherwise similar autocracy. ${ }^{11}$ (With reference to

$11 \quad$ Evidence of the effect of democracy on the degree of centralization can be taken from the histories of many countries that have cycled between democratic and autocratic regimes. Spanish history provides several good illustrations. The Basque country and Catalonia are two of the wealthiest regions of Spain. Both regions have enjoyed limited autonomy for much of the past five hundred years that other regions of Spain have rarely obtained, and have been by far 
figure 1 , a decline in the marginal cost of seeking local autonomy implies that the number of autonomous communities and policy areas increases.)

\section{Historical Examples of Decentralization}

Many contemporary and historical examples are consistent with this analysis. For example, during the early Middle Ages, towns began to prosper as overland trade routes were perfected and expanded. The population of towns and cities increased and land within towns became more intensely used. As community wealth and the value of town services increased, relatively autonomous cities emerged along the major trading routes throughout Europe. Such communities often negotiated a special charter from the ruling barony or bishopry in order to secure local autonomy, or, in some cases, simply acted to secure greater service independence (Pirenne, 1925/1970).

"The charter granted to St. Omer in 1127 may be considered as a point of departure of the political programs of the burgers of Flanders. It recognized the city as a distinct legal territory, provided with a special law common to all inhabitants, with special aldermanic courts and full communal autonomy. Other charters in the course of the Twelfth century ratified similar grants to all the principal cities of the county. Their status was thereafter secured and sanctioned by written warrants. (Pirenne, 1925/1952: 190.)

These medieval charters are relevant for modern Europe, because many of its contemporary urban centers were launched by such medieval charters of privilege.

Of course, there are many other more recent cases around the world in which a few local communities seek or simply claim a degree of local fiscal autonomy that others do not demand. For example, the major Belgian language communities recently negotiated for and received substantial increases in regional autonomy. Similar

the most active seekers of regional autonomy during modern Spanish history. In the past two hundred years there have been several cases where Spanish central governments have shifted briefly between democratic (republican) and authoritarian regimes. Consistent with the above analysis, each time a republican form of governance took hold, local autonomy increased in these two regions of Spain. Each time the autocratic authority regained control, regional autonomy was reduced, but not eliminated. (See for example: Hennessy, A. , 1989, or Brassloff A. , 1989.) Similar examples could be taken from recent developments in South America, Africa and Asia. 
devolutions were negotiated by the Welsh, Scottish, and Northern Irish communities within the United Kingdom and by the autonomous communities of Spain.

Such negotiations are not always successful, but they are common place. For example, close to this author's home, the communities of Northern Virginia, the wealthiest region of Virginia, recently sought special authority to create a local sales tax to fund high construction and mass transit. Local governments received permission from the State of Virginia to impose such taxes-but subject to a local referenda-which sales tax proponents lost.

The communities that secure additional local control over public services are those that are willing to "pay" the most at the margin for additional local services. Others find the political and economic costs of additional local control to be greater than the anticipated benefits; they may be too small, too weak, or too poor to benefit from increased local autonomy or to pay the price required for it. In this manner, the most demanding communities and regions create through their discretionary actions a more decentralized structure of governance, although often an asymmetric one.

\section{Political Limits to Decentralization and Centralization}

\section{A. Contrasting the Degree of Decentralization under the Two Scenarios}

The degree of centralization that emerges from a gradual shift of policy-making authority from local to central confederal governments differs from that of a gradual shift of policy-making authority from central to local governments, because the price of autonomy differs in the two cases. In the over-centralization case first examined, the central government charged local governments the monopoly price for the right of autonomous production. In the under-centralized case, autonomy is freely available, and centralization is voluntarily adopted to the extent that centralization yields local net benefits given that price. Indeed, local governments might have to pay a price to transfer their autonomy to a preexisting central authority. These differences in the price of local authority imply that gradually centralizing states tend to be more decentralized in equilibrium than gradually decentralizing states. 
Differences in the general pattern of local authority are less clear. In the overcentralized case, asymmetric federalism results when relatively more prosperous high demand jurisdictions lobby for greater authority to provide additional services. In the case of the undercentralized state, it is possible that relatively large prosperous states with relatively high service demands will also be the ones that choose autonomy over centralized provision. They have less to gain from economies of scale and coordination, because they already operate at a relatively large scale. On the other hand, as larger states their political risks for membership tend to be smaller than that of smaller states, because they are more likely to be members of the majority coalition.

Another possible pattern of local autonomy involves the order of membership. The analysis suggests that nonmembers generally prefer more autonomy than by those that initially formed the confederation. And, it is nonmembers, of course, that form the pool of potential new members. The analysis above suggests that completely new services, political assurances, or opportunities for lesser degrees of centralized control have to be offered to attract new members. In the latter case, the order of membership will tend to generate asymmetries, with the latest members retaining more local autonomy or being relatively more influential within the central authority.

\section{B. Political Limits to Asymmetric Fiscal Federalization in Democracies: A Centralization Trap}

The political bargains that can be struck within democracies differ from those within autocracies, because majority rule tends to be more constrained by distributional effects than one-man rule. Indeed, majority approval for narrow increases in local authority are relatively easy to secure only in cases in which the new authority can be exercised without imposing externalities on other communities. In such cases, allowing some or all minority communities a bit more local authority is a Pareto superior move, and those uninterested in greater authority for themselves will not attempt to block it for others and may be easily induced to vote in favor of it. However, states or provinces that are uninterested in increased authority for themselves will attempt to block it for others if the local authority sought tends reduce prosperity in regions that do not obtain (or desire) 
the same degree of authority. Moreover, in cases in which local areas already possess powers that impose externalities on the majority, the majority will eliminate those powers, unless those powers are constitutionally protected.

Insofar as a majority of regions or communities are harmed by additional fiscal or economic competition, their representatives will vote against granting other communities additional powers and will repeal such powers if they already exist.

Democratic politics, thus, tends to generate relatively more homogeneous (uniformity) distributions of fiscal and regulatory powers among their subnational governments than stable autocracies, although a more decentralized one as noted above. Asymmetries will still exist within democracies, but their asymmetries favor the majority, tend to have relatively few fiscal externalities, or are constitutionally protected. Such asymmetries are predicted whether or not decentralization increases overall political and economic efficiency.

\section{Internal Organization and Asymmetry Fiscal Federalism}

Asymmetric federalism may take a variety of institutional forms. Specific asymmetries may be created by a nation's constitution by assigning different areas of competency to various regions of the country. Alternatively, the constitution may allow the possibility of alternative internal arrangements that allow the formation of many levels and combinations of fiscal authority. For example, a national constitution may simply allow states to organize themselves into various subnational organizations of states, cities, or counties. An international treaty organization may allow a subset of member states to pursue their own interests within the terms of the treaty.

This possibility allows a range of federal structures that is more complex than normally analyzed by economists and more so than can be fully analyzed here. However, 
it is clear that that many internal organizational structures tend to produce asymmetric forms of fiscal federalism. Figure 3 illustrates one such internal structure.

Figure 2

Internal Asymmetry

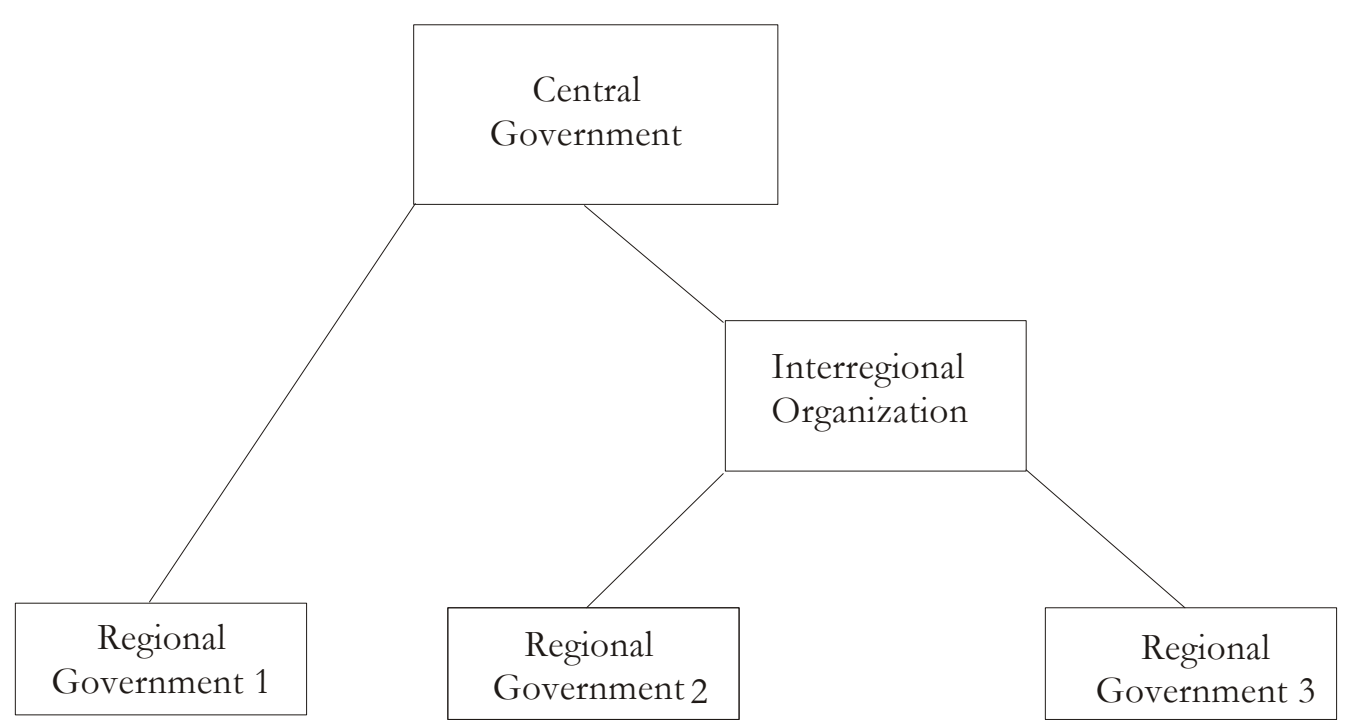

If we interpret the interregional government as another level of centralized control, it is clear that local government 1 retains more autonomy than local governments 2 and 3, because it is not bound by the decisions of the regional government, if the regional government is not granted exclusive areas of competency. Alternatively, if the regional government is granted powers that no member state possesses by itself, local government 1 has less authority than local governments 2 and 3 . In either case, the result is an asymmetric distribution of policy-making authority.

Such internal "governmental clubs" are commonplace. Metropolitan governments often form regional transportation authorities to coordinate regional transport services. Regional environmental councils are often formed via accord or treaty to coordinate the development environmental rules by the state and national governments affected by a regional environmental problem. Nonmembers are not be bound by council decisions, but retain complete local autonomy in the policy areas that others delegate to the central authority. $^{12}$

12 Casella and Frey (1992) and Frey and Eichenberger (1996) analyze the welfare implications of overlapping jurisdictions which, as noted, tends to imply asymmetric forms of federalism. 


\section{Empirical Implications and Evidence from Existing Confederations}

The analysis has generated several predictions about symmetric and asymmetric confederations. First, more encompassing regional and international organizations will specify collective decision making processes and other institutional arrangements that protect the interests of smaller states vis $i$ vi larger members as a means of increasing the scope for mutually advantageous centralization. Second, the number of areas in which competencies are shifted to the central government will tend to increase as such institutions are adopted to reduce political risks associated with centralization. Third, asymmetries emerge whenever a menu approach to confederalism is adopted and as new members or policy areas are added through time to an existing confederation. Fourth, the degree of decentralization is affected by the historical starting point, whether the service areas of interest are initially over- or under-centralized. Fifth, asymmetries tend to be smaller within democratic states than within dictatorships. Sixth, asymmetries that emerge within democracies tend to have few fiscal externalities and/or tend to favor members of long-standing majorities.

Several central authorities and federal systems around the world that have formed gradually and voluntarily through time that seem to accord well with the these predictions. Perhaps, the best modern example is the European Union (EU). Since it inception in 1951, this organization of nation states has proceeded to develop and refine institutions for central governance. Unanimity provides complete protection of the interests of small states on major constitutional decisions and such areas as culture, regional and social funds, and foreign policy. ${ }^{13}$ Normal day-to-day decision making also tends to favor smaller states (Bindseil and Hantke, 1997) through the use of super

Their emphasis is on how competition between or within states can be usefully promoted. We do not emphasize the competitive implications of federalism but rather the political and economic advantages of decentralized control. As indicated by these and other more traditional analyses of federalism, competition among communities also tends to improve the economic performance of local governments, and therefore provides another normative defense of federalism.

13 Consistent with this, Bendar, Ferejohn, and Garrett (1996) note that the areas in which public support is greater for the EU are those which rely upon unanimity for decision making. The move to majoritarianism embodied in successive integrative steps lessened public support for the EU. 
majorities and weighted voting. The EU has to a large extent implemented a generality rule, in that policies are intended to apply uniformly to all EU members. Consistent with the analysis, the range of policies brought into EU authority is gradually increasing as institutional protections have proven themselves and been extended.

Significant asymmetries exist, however, within major policy areas where menu-like choices are possible. The broadly interpreted European community is characterized by a series of treaties that can be signed independently of one another. The traditionally neutral states of Austria, Denmark, Iceland, Finland and Sweden remain outside the Western European Union, the EU's defense arm. Ireland, Norway and Liechtenstein remain outside of the EU, but are members of the European Economic Area which allows significantly greater national autonomy with respect to fisheries, agriculture, indirect taxation, and tariffs than full membership does.

Exceptions to the core treaties of the EU have been granted at constitutional moments: at times when new services have been brought under EU authority or as new members have been added. Confederal asymmetries largely take the form of exemptions that provide additional local autonomy over specific policy areas. The United Kingdom has obtained "opt outs" from the Social Charter of the Maastricht Treaty. The United Kingdom, Denmark, and Sweden retain more autonomy over macroecomic policy than other member states by opting out of the European currency union. Some recent members have received permission to maintain stricter environmental standards in some areas (subject to EU review). Consistent with the analysis, the original members (Germany, Italy, France, Belgium, Netherlands, and Luxembourg) have given up relatively more autonomy to the EU than have subsequent members.

\section{Conclusion and Summary}

This chapter has analyzed the politics of decentralization. The analysis demonstrates that the degree of centralization is affected by both political and economic considerations. Moreover, no single uniform level of centralization emerges, but rather the degree of centralization differs according to the original circumstances of the polities involved and the distribution of demands for regional autonomy. Decentralization is not 
an exogenous feature of a polity, as often assumed, but rather an endogenous result of ongoing negotiations over the distribution of policy-making authority among central and local governments. The latter implies that the degree of local autonomy is likely to vary by region, because the demand for local authority tends to vary according to local needs, income, and organization.

The processes of centralization and decentralization analyzed are broadly contractarian and Coasian (1960) in spirit. However, in contrast to the unique result of the classic Coase discussion of agreements to internalize externalities, there are many possible agreements that can be negotiated between levels of governments and among governments at a particular level of governance. As in any Edgeworth box, initial "endowments" affect which parts of the constitutional contract curve may be reached via a series of voluntary agreements. Thus, different historical starting points allow communities to reach different regions of the Pareto constitutional frontier via voluntary exchange.

Although the analysis has mainly been concerned with explaining some fundamental institutional features of federal and confederal systems of governance, the conclusions parallel and extend those of the conventional welfare-economic analysis of fiscal federalism, which largely neglects institutional and political aspects of federal states. The analysis suggests that intragovernmental negotiations often produce efficiency increasing political institutions, because improved political institutions often produce economic benefits for both central and local governments. For example, the rule of law and the generality principle allow economies of scale and scope to be more fully realized by increasing membership insofar as such legal constraints reduce the cost of being a member of a politically disadvantaged group (Congleton, 1997). Supermajority requirements, regional vetoes, weighted voting, bicameralism, and explicit power sharing arrangements similarly reduce the probability that a region or member state will find itself powerless in the central government. Menu systems of fiscal federalism can also promote efficiency by facilitating centralization in policy areas and for groups of communities in which centralization is efficient, without imposing it in areas where it is not. Such 
institutions encourage the formation and continuation of centralized fiscal systems, and also allow government services to be provided more efficiently.

Competition among local governments within an asymmetric federal system, however, differs from that in symmetric systems, because there are supply-side as well as demand-side variations in services in asymmetric systems. Clearly, only communities that have the power to set tax and service levels can compete on such taxes and services. Consequently, asymmetries in fiscal and regulatory authority often generate asymmetries in population and wealth as favored cities or regions adjust their fiscal packages to attract new capital and labor, while other cities and regions that lack the power to make their own policies fall behind. Many of the negative consequences of regional favoritism can be reduced by reducing the price of local autonomy, as with a menu-based systems in which communities are free to join or opt out of centralized control.

Overall, the analysis suggests that asymmetric federalism is likely to emerge in a wide variety of circumstances and is likely to be efficiency-enhancing insofar as local governments promote local interests. The latter is fortunate indeed, because asymmetric solutions are likely to become increasingly widespread around the world as regional organizations and globalization induce disparate countries and regions to pursue new mutual advantages from cooperation, while minimizing the political risks associated with centralized control. 


\section{References}

Bindseil, U. and Hantke, C. (1997) "The Power Distribution in Decision Making among EU Member States," European Journal of Political Economy 13: 171-85.

Bendar, J., Ferejohn, J. and Garrett, G. (1996) "The Politics of European Federalism," International Review of Law and Economics 16: 279-94.

Brassloff, A. (1989) "Spain: the State of the Autonomies," in M. Forsyth (ed) Federalism and Nationalism. London: Palgrave McMillan.

Brennan, G. and Buchanan, J. M. (1977) "Towards a Tax Constitution for Leviathan," Journal of Public Economics 8: 255-73.

Brennan, G. and Buchanan, J. M. (1980) The Power to Tax. Analytical Foundations of a Fiscal Constitution. Cambridge: Cambridge University Press.

Browning, E. K. (1987) "On the Marginal Welfare Cost of Taxation," American Economic Review 77: 11-23.

Buchanan, J. M. and Congleton, R. D. (1998) Politics by Principle Not Interest. Cambridge: Cambridge University Press.

Buchanan, J. M. and Tullock, G. (1962) The Calculus of Consent. Ann Arbor: University of Michigan Press.

Casella, A. and Frey, B. (1992) "Federalism and Clubs. Towards an Economic Theory of Overlapping Political Jurisdictions," European Economic Review 36: 639-46.

Coase, R. E. (1960) "The Problem of Social Cost," Journal of Law and Economics 3: 1-44.

Congleton, R. D. (1997) "Political Efficiency and Equal Protection of the Law," Kyklos 50: 485-505.

Congleton, R. D. (1995) "Towards a Transactions Cost Theory of Environmental Treaties: Substantive and Symbolic Environmental Agreements," Economia Delle Scelte Pubbliche: 119-39.

Congleton, R. D. (1994) "Constitutional Federalism and Decentralization: A Second Best Solution," Economia delle Scelte Pubbliche 12:15-29.

Congleton, R. D., J. Bacarria, and A. Kyriacou (2003) "A Theory of Menu Federalism, Decentralization by Political Agreement," Constitutional Political Economy 14:167-90.

Elazar, D. J. Ed. (1991) Federal Systems of the World: A Handbook of Federal, Confederal, and Autonomy Arrangements. Essex: Longman Group Limited. 
Frey, Bruno and Eichenberger, Reiner (1996) "FOJC. Competitive Governments for Europe," International Journal of Law and Economics 16:315-27.

Hennessy, C. A. M. (1989) “The Renaissance of Federal Ideas in Contemporary Spain,” in M. Forsyth (ed) Federalism and Nationalism. London: Palgrave Macmillan.

Inman, R. P. and Rubinfeld, D. L. (1997) "Rethinking Federalism," Journal of Economic Perspectives 11: 43-64.

Kyriacou, Andreas P. (1998) "The Constitutional Political Economy of a Reunified Cyprus," Mimeo: Universitat Autonoma de Barcelona.

Moraw, P. (1989) "Cities and Citizenry as Factors of State Formation in the Roman-German Empire of the Late Middle Ages," in Tilly, C. and Blockmans, W. P. Eds. Cities and the Rise of States in Europe, A.D. 1000 to 1800. Boulder Co: Westview Press, p. 631-62.

Molander, P. (2004) Fiscal Federalism in Unitary States. Dordrecht, NL: Kluwer Academic Publishers.

Mueller, D. C. (1989) Public Choice II. Cambridge: Cambridge University Press.

North, D. C. (1991) Institutions, Institutional Change, and Economic Performance. Cambridge: Cambridge University Press.

Oates, W. E. (1972) Fiscal Federalism. New York: Harcourt, Brace, Jovanovich.

Olson, M. (1993) "Dictatorship, Democracy, and Development," American Political Science Review 87: 567-76.

Olson, M. (2000), Power and Prosperity: Outgrowing Communist and Capitalist Dictatorships. New York: Basic Books.

Olson, M. and McGuire, M. C. (1996) "The Economics of Autocracy and Majority Rule: the Invisible Hand and the Use of Force," Journal of Economic Literature 34:72-96.

Olson, M. and Zeckhauser, R. (1966) "An Economic Theory of Alliances," Review of Economics and Statistics 48: 266-79.

Pirenne, H. (1925/1970) Medieval Cities: Their Origins and the Revival of Trade. (Translated by F. D. Halsey) New Jersey: Princeton University Press.

Qian, Y. and Weingast, B. (1997) "Federalism as a Commitment to Preserving Market Incentives," Journal of Economic Perspectives 11: 83-92.

Ra'anan, U., Mesner, M., Armes, K. and Martin, K. Eds. (1991) State and Nation in multiethnic Societies: The Breakup of Multinational States. New York: Manchester University Press.

Requejo, F. (1996) "Diferencias Nacionales y Federalismo Asimétrico," Clares de Razón Practica 59: 24-37. 
Tiebout, C. (1956) "A Pure Theory of Local Expenditures," Journal of Political Economy 64: 416 $-24$.

Tilly, C. and Blockmans, W. P. Eds. (1989) Cities and the Rise of States in Europe, A.D. 1000 to 1800. Boulder Co.: Westview Press.

Vaubel, Roland (1994) "The Public Choice Analysis of European Integration: A Survey," European Journal of Political Economy 10: 227-249. 